\section{ECONOMICS}

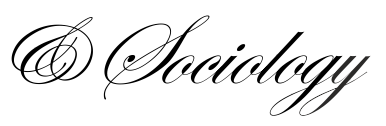

Jerzemowska, M., \& Koyama, Y. (2020). The board as an example of Japanese corporate governance system hybridization: An outline of the problem. Economics and Sociology, 13(3), 171-202. doi:10.14254/2071-789X.2020/13-3/11

\title{
THE BOARD AS AN EXAMPLE OF JAPANESE CORPORATE GOVERNANCE SYSTEM HYBRIDIZATION: AN OUTLINE OF THE PROBLEM
}

\author{
Magdalena Jerzemowska \\ University of Gdansk, \\ Gdansk, Poland \\ E-mail: \\ magdalena.jerzemowska@ug.edu.pl \\ ORCID 0000-0002-9282-0000
}

Yoji Koyama

Niigata University,

Japan

E-mail: ZAC00343@,nifty.com

Received: April, 2020

1st Revision: August, 2020

Accepted: September, 2020

DOI: $10.14254 / 2071-$

789X.2020/13-3/11
ABSTRACT. This paper argues that hybridization is a process that has been going on for decades in Japan and has contributed to improvement of Japanese corporate governance, and that the regulations regarding the board of directors are a good example of this hybridization process. The paper outlines the main changes within Japanese corporate governance system and identifies their determinants. Three main waves of hybridization of Japanese regulations and corporate governance are identified, along with three functioning structures of Japanese boards, and their strong and weak points. The company with statutory auditors (with Kansayaku Board), the company with Three Committees - nomination, audit, and remuneration - and the company with an Audit and Supervisory Committee are presented as evidence of this hybridization process. The paper addresses the research question: why has hybridization rather than convergence resulted in an improvement of Japanese corporate governance? The method of critical analysis is applied to academic literature sources, legal acts, and corporate governance regulations. The article contributes to a reduction in the research gap in Polish academic literature in the field of Japanese corporate governance, especially with respect to Japanese boards.

Keywords: corporate governance, systems, board of directors, board of statutory auditors.

\section{Introduction}

Corporate governance may be defined as a theoretical framework to examine how identities and interests of capital, labour, and management are shaped in relation to their institutional contexts (Aoki, 2001; Aguilera, Jackson, 2002). National institutional systems provide these contexts, by creating formal and informal rules to which domestic and foreign firms must adapt their governance and ownership structures (Hopt, 2011, p. 6). The economic, legal, social, and cultural determinants lead to path-dependent developments in those areas (Wright, Siegiel et al, 2004, p.47; Bebchuk, Roe, 2004). Thus, corporate governance systems change over time, and country-specific frameworks create patterns of influence that 
stakeholders exert on managerial decision-making (The Oxford Handbook of Law and Governance, 2015, p. 3.1). They define social relations and institutional arrangements determining who controls corporations, whose interests corporations serve and how risks and rewards are allocated among stakeholders. The factors that influence corporate governance may cause a convergence, divergence, or hybridization of corporate governance models.

Convergence means coming together, and divergence means moving apart (Yoshikawa, Rasheed, 2009, p. 389). According to academic literature (Gordon, Ringe, 2015; Haxi, Ees, 2010; Hansmann, Kraakman, 2000); Augilera, Jackson 2018; Jeffers, 2005; Khanna, Palepu 2004; Nestor, Thompson, 1997), the most important drivers of the corporate governance systems' convergence are:

- globalization of governance, stimulated by the IMF, the World Bank, the OECD, the G20 group, and the FSB;

- internationalization, deregulation, and integration of financial markets;

- corporate governance codes, especially the OECD Principles of Corporate Governance (1999, 2004, 2015), that follow the comply or explain principle;

- the ongoing competition among governance systems, globalization of competition, institutionalization of investments, and harmonization of accounting rules;

- cultural and institutional factors, especially development of an internal culture by corporations that gradually grow away from specific national characteristics;

- competition in attracting foreign institutional investors;

- the possibility to gain international education, qualifications, and skills;

- dominance of a shareholder-centred ideology of corporate law among the business, government, and legal elites in key commercial jurisdictions;

- addressing problems that are faced by all corporations.

Factors impeding the convergence (divergence) of national governance systems include structure-driven and rule-driven path dependencies (Licht, 2001). According to academic literature (Kwok-Bun, Peverelli, 2018; Karolyj, 2016; Siems, 2010; Carneya, Estrinb, et al., 2018; Branson, 2001; Gilson, 2004; Hansmann, Kraakman,2000; Palkar, Lellapalli, 2015; Augilera, Jackson, 2002) the most important amongst them are:

- the loss of a benchmark - the dominant models have proved to be vulnerable to failure and systemic weaknesses;

- resistance to the institutional investors' power;

- lack of governments' interest to eliminate obstacles to the free flow of capital across countries and to full integration of capital markets;

- the use of the "comply or explain" principle because governments try to retain traditional practices, but in order to attract foreign capital, they must introduce international regulations too;

- corporate culture values in each country significantly impact corporate governance, as they influence how governance principles are recognized and applied in practice;

- culture and traditions of a particular country.

The above mentioned factors reveal that there are strong reasons to support the notion of convergence or divergence of corporate governance models. According to current academic literature (La Porta et al., 1999; Gilson, Milhaupt, 2005; Drobetz, Momtaz, 2019; Khanna, Kogan, Palepu, 2006; Yoshikawa, Rasheed, 2009, p. 4; Aguilera, Jackson, 2010), convergence in form (de jure) is what currently prevails. Convergence in function (de facto) is market-driven, has an evolutionary character, and needs more determination, time, and efforts. Significant cultural differences existing in national systems mean that convergence in the true sense is very difficult to achieve. It may be questioned as to whether it is really required. Gilson (2004) stated that neither convergence, nor divergence, but the co-existence of both forces for 
convergence and forces against them are in some state of uneasy equilibrium (Gilson, 2004, p.16). The increasing interaction between players from different parts of the globe leads to gradual emergence of a single business culture (Kwok-bun, Peverelli, 2010). Aguilera and Jackson argue that national models are influenced by multiple institutions that produce interdependent effects on organizations, but that such effects are not complementary and do not lead to a "coherent" national model with efficiency traits (Augilera and Jackson, 2010). These systems are experiencing a hybridization process, in which forms become separated from the existing practices and recombine with new forms in new practices (Pieterse, 1994, p. 165). These transferred organizational practices undergo adaptation. Hybridization involves transformation of imported institutions via the interaction with different national and institutional contexts and the attempts to reconcile two approaches initially seen as contradictory to each other. In such a way an original configuration emerges - new forms in new practices (Miyajima, 2012; Pietrese, 1994, p.161-184). Thus, hybridization causes growing heterogeneity of organizational practices within national systems. Through the process of trial and error the outcome of confrontation between newly imported practices and the existing practices is highly uncertain, leading to divergent corporate governance models (Lee, 2014). Japan's corporate governance is a good example of hybridization.

The aim of this paper is to demonstrate that hybridization is a process that has been going on for decades in Japan, contributing to the improvement of Japanese corporate governance, and that the regulations regarding boards of directors are a good example of this hybridization process.

To achieve this aim, changes in Japanese corporate governance system and their determinants are highlighted. The three main waves in hybridization of Japanese regulations and corporate governance (starting in 1858, 1945, and 2004) are characterized, and the three functioning structures of Japanese boards are described along with their strong and weak points as a result of and evidence of the hybridization processes.

This paper contributes to a better understanding of the historical evolution of Japanese corporate governance through the selection and critical analysis of academic literature and legal regulations - hard and soft - that explain the key changes in Japanese corporate governance from the nineteenth century to the present day. It is argued that the process of hybridization of Japanese boards took place in three stages, driven by the exogenous shocks, i.e., the opening up to the world back in 1858, American occupation after WWII, and the financial crisis at the beginning of the XXIst century. It is also argued that hybridisation is more beneficial than convergence for the Japanese business environment. The paper reduces the existing research gap in the field of Japanese corporate governance, particularly with respect to hybridization of governance structures.

\section{The three waves of the hybridization of the Japanese corporate governance system - a background for analysis}

The history of the development of corporate governance models reveals that countries often adapt some laws and institutions from other systems. However, it does not always lead to the convergence of systems, but rather to modifications creating a new hybrid form. Japan is a good example of such developments especially since the second half of the nineteenth century. Opening up to the world in 1854, after 250 years of isolation, the country began to build a capitalist economy and speedily caught up with the world's most developed countries using a hybridized approach. Many publications have been devoted to the genesis and development of Japanese corporate governance. Their authors may agree on the facts but they do not assess their significance and consequences in the same way. For this reason the 
descriptions of hybridization and its various stages requires making choices and evaluations of cited publications thus enabling the formulating of one's own concept of the process.

On the basis of literature three main waves of hybridization of Japanese regulations can be identified which are formally connected with three stages in the development of Japanese corporate governance - the pre-war Anglo-Saxon capitalist system, the post-war system of prosperity capitalism, and the current market-oriented system (Patrick, 2004).

The starting point for the first and the biggest, in scale, hybridization of Japanese corporate governance system was the action of the US Navy (Commodore M. Perry, 1853), which forced the Tokugawa government to open up Japan to the world following over two centuries of isolation. Abolition of the shogunate enabled the Meiji (enlightened rule combining modern advances with traditional Eastern values) Restoration, which reinstated Imperial Rule and implemented important political, economic, military, cultural and social transformations leading to the modernization of Japan. The Meiji government managed to shift Japan from an agriculture, feudal country into a modern capitalist economy within a few decades. To impose and accelerate these processes the best Western achievements were used and hybridization processes played a very significant role in this transformation. Western experts were employed and scholars were sent abroad to study industrialization, banking systems, and western laws. The newly acquired knowledge and best practices were then used to create, or to modernize, national and private institutions and the country. Modernization of law had become a priority as people did their business according to old Japanese customs and practices which were not uniform across the country and were not always enforced by the courts.

The government implemented important reforms such as the establishment of the Ministry of Finance in 1869, the Tokyo Stock Exchange in 1878, and the Bank of Japan in 1878. US law was used to introduce the National Bank and the New Currency Act in 1872. The enactment of the National Bank Act enabled the creation of the first modern corporations in Japan (Shishido, 2001, p.653-677). Commercial banks were modeled according to the American system (Yamaguchi, 1950). However, these first attempts at Americanization were not successful. The failure of the first National Bank Model resulted in the introduction of the German system based on a central bank. (Shisido, 2001, p.653-677). The first Japanese Commercial Code, enacted in 1890, was modelled by F.H. Roesler on the German Commercial Code of 1861. However, it was considered too foreign, was said to disregard Japanese customary business practices and it had to be changed (Bird, 2005, p.528). In some cases the Code was not able to be adapted to Japanese business conditions as it confounded the public and private law for example. The provisions in the Commercial Code were sometimes contradictory to those of the Civil Code which had been compiled by a Frenchman, and modelled on the French Civil Code, and there were many redundant provisions in the two codes (West, 2001). The new institutions undermined traditional norms creating uncertainty around what had been previously clear business dealings. For these reasons, the First Commercial Code, based on the Franco- German system (Japan Commercial Code, 1890), was revised, and in 1899 the present Commercial Code, based on the German Commercial Code of 1897, was promulgated and in the same year adopted. It retained some of the basic structures of the old Code, especially the law of bankruptcy, which is still in force today. However the English Bills of Exchange and Sale of Goods Acts and the American Negotiable Instruments Law and Uniform Sales Act were also implemented in amending the laws (Braucher, 1961).

By 1878 the government (concept Wealthy Nation/Strong Militarily), had simplified the Japanese currency, created a market for government bonds, a national bank, and a banking system. Inspired by Western thought it revamped its education system, developed industries, introduced land tax reform and built up an army (universal conscription). Within a few years, Japan adopted parliamentary democracy modelled on the German Diet; compulsory public 
education modelled on French and German schools and universities; a modern army fashioned after that of Prussia and a fleet modelled on the U.K. Royal Navy. Religious freedom, social mobility, and land reform became official policy. Japan was adopting the best solutions and implementing them to fit their own needs. After overcoming enormous difficulties, Japan managed to create a system in which the capital market played an important role as well as delivering maximization of returns for investors. It was also characterized by profit-responsive management salaries; employment of external directors; governance of companies by large shareholders; hostile takeovers; high turnover rate of employees; joint stockholding system; inhouse promotion to management; and an emerging selection of management from among core employees. 'The company' was supervised by a statutory auditor (Dore, 2000, s.32-33). The system was more like the German model than the US model (Patrick, 2004). Japan had adapted a continental corporate governance model and a financial system similar to the American one. Thus, hybridization played a very important role in the modernization of Japan and a combination of national and imported laws and other factors formed a unique Japanese model of corporate governance.

The young Meiji government not only created the infrastructure for future industrialization but was actively involved in establishing and expanding companies. It performed the first massive privatisation thus enabling the formation of "pyramidal business groups". This structure (devised in the 19th century by British trading firms), allowed wealthy families to use public investors' money to control corporate assets worth more than the sum total of their own personal wealth. As a result, important areas of the economy were gradually taken over by large family businesses called Zaibatsu (the Japanese variant of the pyramidal business group) (Morck \& Nakamura, 2007). They were defined "as groups of diversified businesses owned exclusively by a single family or an extended family" (Okumura, 1984; Morikawa, 2002). Zaibatsu were multi-tiered structures with a lead business at the apex. They were foreign technology importers and therefore highly regarded by the Meiji government and they were supported by subsidies and contracts aimed at accelerating their development and modernizing the economy.

However, since the beginning of the Showa epoch corporate governance had undergone changes impelled by expansionist government policies which favoured the implementation of specific elements into this system. The military government, which seized power in the 1930s, took control of the investment policies and strategic decisions of the country's great corporations. In consequence the Zaibatsu's activities became paramilitary, and the banks became responsible for financing production for war. This led to a formation of strong relationships between these entities (bank centered controlled financing), based on Japanese ideology and tradition. The joint stock holding system of Zaibatsu families prevented individual shareholders from intervening in management decisions (Shishido, 2001, p.659), the interests of shareholders became less important and banks began to take over the functions of statutory auditors (double supervision): the importance of Zaibatsu managers and employees increased. The system became bank-dominated and stakeholder-oriented. It was based on Western rules (American and European), whose shape and scope of implementation were determined by Japanese culture, tradition and needs. (Braucher, 1961; Dore, 2000; Yamamura, Streeck, 2003, p.1-50; Hoshi, Kashyap, 2001, s.6). The result was the emergence a unique (hybrid) Japanese model of corporate governance.

The second wave of changes of Japanese corporate governance had begun with enactment of the Dodge Line policies and the post-war system of prosperity capitalism. After the Second World War the American occupying authority intended to destroy the economic base of the Japanese military and prevent monopolistic market concentration. Americans had a New-Deal-nuanced vision of democracy that relied on law as a vehicle to effect social and 
political change (Morck, Nakamura, 2007). Five major reforms to secure human rights were enforced concerning emancipation of women, promotion of trade unions, liberalization of school education, abolishment of despotic government, and democratization of the economy. The law established basic human rights such as, freedom of speech, freedom of meeting, freedom of association, equal rights for both sexes (Koyama, 2003). Japan got a new Constitution (1947), also the Law on trade unions and Amendment of the law on adjustment of land, both came into force in 1946 (the land reform was completed in 1949). These changes were revolutionary for very traditional Japan and ended the Absolute Imperial System.

In 1947 a Japanese Antimonopoly Law drafted by P.T. Kime and J. Salwin came into effect making holding (Zaibatsu) companies illegal. They were to be dissolved into smaller companies by selling their shares to the public, their executives were purged (West, 2001). It was also forbidden to use their names and logos (Baum, 1994).

American lawyers created the Trade Association Law in 1948. Further to that the Japanese amended their Commercial Code and the Revised Model Business Corporation Act (MBCA) on which most state corporate statutes are based.** In consequence of revisions made largely along the lines of this Act, shareholders' rights were increased, boards of directors were established, the pre-war power of statutory auditors was curtailed, individual share ownership was fostered, and concepts of director accountability were introduced (West, 2001).

These newly imposed revolutionary changes caused the second wave of hybridization of Japanese laws and practices and in consequence initiated the development of the Main Bank System.

By 1948 the global political situation had changed, and the United States began to see Japan as a strategic partner with a strong economy (Miyashita, Russel, 1994, p. 34). With the change of policy the process of dissolution of the Zaibatsu was stopped, many of them were reestablished, and the use of their names and logos was no longer forbidden (Morikawa, 2002: 238). To rebuild an economy devastated by war, the Japanese government made a series of decisions to control foreign investments, to ration capital, and make people's savings flow into banks. A clear separation of banking and trading in securities (Securities and Exchange Act of 1948 (\&65) was introduced. Banks were the only source of capital for enterprises (till 1980s) because foreign capital financing was prohibited and they were the only option for investing household savings. Soon, banks became the centre of the financing system for the reconstruction and development of Japan. This important role strengthened their position as the dominant financial institution (Nakamura, Morck,2007). In 1949 the ban on cross ownership of shares was lifted and companies grouped around banks could hold and buy each others shares. New conglomerates called keiretsu emerged. Keiretsu (horizontal or vertical) are defined as the close, long- term business relationships established by large corporations with selected groups of smaller firms linked through investment and the exchange of personnel. Some of them emerged out of former Zaibatsu but others were new groupings of companies. The keiretsu lacked parent corporations operating as holding companies; the influence of family, common in a Zaibatsu, disappeared and member companies were independent (Kensy, 2001, p. 208-209). The Main Banking system had developed fully by the 1970s (The Japanese Main Bank System; The Relevance for developing and Transforming Economies, 1994 p. 150). It is characterized by a high level of stock ownership by affiliated banks and companies with strong, long-term links (Patrick, 2004; Ahmadjian, 2008). The Main Bank holds shares in the companies of the group and has representatives on the board of directors, it also plays a central role in financing firms and monitoring management (Corporate Governance in Japan, 2017; Braendle, Noll, 2006; Ahmadjian, 2008). It is expected to provide crisis insurance in times of distress (bailing out a troubled company), being the solution to the agency monitoring problem and impose new management and/ or strategies in the event of poor performance. This 
mechanism avoids expensive formal bankruptcy procedures and safeguards against premature liquidations that disrupt long-term business relations with suppliers or employees and also internalizes the market for corporate control (Gilson, Roe, 1993). Major shareholders protect the firm from the threat of hostile takeover bids. Main Bank relations, therefore, meant establishing long-term relationships with an enterprise, supporting the enterprise's activities and assuming the risk in respect of its operations. The benefits of such a system were much higher than its costs (Patrick, 2004). The Main Bank relationship was a informal set of regular practices, institutional arrangements, and behaviour that constitute a system of corporate finance and governance (Aoki and Patrick, 1994, p. xxi). The interrelated key players in this model are the Main Bank, keiretsu (industrial groups linked by trading relationships, crossshareholdings, and interlocking directorships), management, and government (Tricker, 2015, p.152).

Japan is also well known as a stakeholder model of corporate governance, where employee interests play a predominant role (Dore, 2000). This idea of the firm as a community of people is manifest in several human resource management practices geared to mobilize longterm commitment to the enterprise. As communities, companies have three "treasures" lifetime employment, the seniority wage system, and corporate trade unions (Inagami, Whittaker, 2005). Lifetime employment is a norm for regular and usually male employees in large firms which became institutionalized together with the emergence of cooperative enterprise-based unions in the early post-war period. It reflects strong legal constraints on dismissals, motivates firms to invest in firm-specific skills and maintains internal flexibility of employees with regard to job functions within the firm or related firms. This system is supported by seniority-related wages, a rank-hierarchy system of promotion, training through job rotation, and a strong socialization into company culture (Hoshi, Kashyap, 2001).

The Japanese classic model of corporate governance results from the corporation's longterm relationship with banks and the long-term commitments to employees. This allowed firms to have a lower cost of capital and higher investment as the capital market was not a common source of finance. The model is associated with strong state intervention and corporate governance is concerned with ensuring that firms are run in such a way that society's resources are used efficiently and that due consideration is given to a a range of stakeholders (Allen, Zhao, 2007). The bundle of characteristics of this system is supplemented by the banks' longterms relationships with client firms thus helping to overcome information asymmetries; offering financial services and advice; ownership concentration; the role of government in credit allocation; weak disclosure standard. Few legal rules to ensure transparency and to protect minority shareholders (Aoki \& Patrick, 1994). Okabe (2009) means that Japanese firms, since the end of World War II until the 1980s, had three characteristic features - they were strongly growth oriented, did not give consideration to shareholders and share pricing (dispersion of company ownership), and were group oriented.

Japanese firms were traditionally financed by Main Bank which supervised the management team. The finance minister (very broad powers) headed the financial system and convoyed banks, hence the name Convoy System (Hattori, Maeda, 2000; Corporate Governance in the 21st Century., s. 2-3, 2009; Ahmadjian, 2008; Okabe, 2009). The Japanese model at that time was a good alternative to the American one.

An analysis of the legal base and specific features of the unique Japanese Main Bank System - shows that it is the result of the impact of several external and internal determinants. Amongst them the post-war policy of the occupying authorities (imposed Americanization), interventionist economic policy of the state, efforts to protect from Americanization, and that Japanese tradition and culture had the greatest impact on its shape. Japan's model of corporate 
governance follows the logic of "networks," which mixes hierarchy-based and market-based elements of governance under a hybrid regulatory regime (Raupach-Sumiya, 2000).

The third wave of hybridization takes place with emergence of the market-oriented system that was intended to replace the traditional model, highly criticized in the last decade of the 20th century (Larcker, Tayan, 2011, s.48; Yao, 2009). The prolonged stagnation of the economy and the growing share of foreign investment capital resulted in Japanese politicians' developing interest in the shareholder-oriented model, capital markets and the transparency necessary for attracting foreign investment into Japan (Corporate governance in the 21st Century..., 2009; Dore, 2007; Koyama, 2003). In the mid-1990s, Japanese firms began to come under pressure from the Corporate Governance Forum of Japan and The US and British investment funds, which had dramatically increased their holdings of Japanese equities, to adopt US-style governance practices, considered best at that time. They required independent, smaller boards more oriented towards shareholder value , higher numbers of independent directors, and more transparent financial reporting. However, the modernizations to be introduced were controversial because some managers, especially the Japanese Business Federation (Nippon Keidanren), strongly defended the Japanese system of the company as a community, controlled by insiders (Ahmadjian, 2008).

The breakthrough year for the Japanese economy and corporate governance was 1997, when the government announced the Big Bang reform focused on deregulation and internationalization of the economy and construction of a free, fair, open, competitive capital market policy (Jacoby, 2002; Kuepper, 2017). It initiated the implementation of the Plan for Strengthening the Comprehensiveness of Japan's Financial and Capital Markets, which was aimed at increasing Japan's competitiveness on the international scale. It refocused Japanese company law on American and British regulations, OECD Corporate Governance Principles (2004) and recommendations of the International Monetary Fund (IMF) starting the so called Internal Americanization (Shishido, 2007, p.323; TSE, 2004, s. 7).

Many major institutional changes had been made as part of the deregulation of the economy. The process of the amendment of company and commercial laws as well as adjustment of regulations regarding trading in securities had begun. The Tokyo Stock Exchange (TSE) and the Keidanren published good corporate governance practices (based on OECD), the implementation of which was voluntary (Okabe, 2009).

Commercial Law was reformed in two stages - in 2006 and 2015. Both stages resulted in the need to make its provisions compatible with other legal acts governing the economy and the financial system (Corporate Governance in the $21^{\text {st }}$ Century, 2009; Shishido, 2001). The changes in the legal and financial environment made it difficult for firms to maintain the postwar system of governance and deteriorating advantages of cross-shareholding. The internal Americanization began with the initiating of a new stage of hybridization of Japanese corporate governance.

The 2006 amendments in the Commercial Code adopted the American principles of shareholder preference and responsibility into Japanese regulations and strengthened the rank and importance of corporate governance (Itami, 2005; Shishido, 2001, s.323; Nakamura, 2011). The Big Bang Reform resulted in the publication of the following important documents:

- 2005 - the overall reform of the Companies Act

- 2006 - Commercial Code - implemented US law into the Japanese legislative system - strengthening shareholders, accountability, and corporate governance (Internal Americanization)

- 2007 - The Financial Instruments and Exchange Act (called Japanese SOX)

- 2009 - a new version of Principles of Corporate Governance for Listed Companies. 
The second wave of changes, starting the new era of Japanese corporate governance, was initiated in June 2013, by the government adopting the Japanese Revitalization Strategy and the three arrows of abenism focused on structural reforms, monetary and tax policy. The following acts, directed towards revitalization of Japan, were published:

- 2014 - Financial Services Agency (FSA): Principles for Responsible Institutional Investors, called Japan's Stewardship Code (based on the UK Stewardship Code and comply or explain principle) (amended in 2018)

- 2015 - Amendment of the Companies Act and Japan's Corporate Governance Code (based on important international corporate governance recommendations),

- 2015 - Guidelines for the Prevention of Bribery of Foreign Public Officials (METI Guidelines),

- 2016 - The Tokyo Stock Exchange (TSE): New Listing Guidebook for Foreign Companies (comply or explain principle),

- 2016 - Japan's Unfair Competition Prevention Act (UCPA) compatible with the US' Foreign Corrupt Practices Act and the United Kingdom's Bribery Act 2010,

- 2016 - TSE: Principles for Listed Companies Dealing with Corporate Malfeasance,

- 2017 - FSA: Principles for Effective Management of Audit Firms (the Audit Firm Governance Code),

- 2018 - TSE: Japan's Corporate Governance Code Seeking Sustainable Corporate Growth and Increased Corporate Value over the Mid- to Long-Term,

- 2018 - Tokyo Principles for Strengthening Anti-Corruption Initiatives by the United Nations Global Compact Network in Japan (UNGCN),

- 2018 - Financial Services Agency: Guidelines for Investor and Company Engagement

- 2018 - Japan Exchange Regulation (JPX-R): Principles for Preventing Corporate Scandals.

The amendments concerned the company and commercial laws, accounting, mergers and acquisitions, transactions in financial instruments and the diversification of corporate governance structures, especially internal supervision in companies (Patrick, 2004, Aronson, 2014; Lovels, 2016; No\&T Japan Legal Update, 2017).

The Cabinet Office announced a New Economic Policy Package in early December 2017. These policies focused on three key areas for the next three years: human resource development, supply system innovation, and how Japan will respond to additional fiscal demands. Under the supply system heading is a section called Corporate governance revolution, this outlined the government's intention to develop guidance aimed at encouraging decisive management decision-making, effective use of retained earnings, the improvement of the processes of CEO appointment and dismissal, reduction of cross shareholdings, and the participation of corporate pension funds in stewardship activities. These five points were reflected in the amendment of the Corporate Governance Code, released in 2018 (The Japanese Institute of Certified Public Accountants, 2018, p.209). Thus, the government policy to make Japanese corporate governance compatible with the international standards is continued in a "soft" way, leading to further hybridization.

Analysis reveals that hybridization is important in improving Japanese corporate governance and responding to problems Japan has been suffering since the beginning of XXI century. Despite all the changes towards Internal Americanization and pressure from foreign investors, there is still a sharp difference between the Japanese and the American systems of corporate governance. The strong resistance to Americanization makes convergence impossible. Therefore, hybridization is becoming the only solution to combining the benefits 
of the two models. This process can be seen when examining the board of directors' structures that Japanese big companies can now choose

\section{The structures of the Japanese board and hybridization}

The organisational structure of a stock company (kabushiki kaisha or KK most common corporate entity in Japan) typically consists of shareholders (Annual General Meeting - AGM), board of directors, representative director(s), and statutory auditors. A shareholders' meeting is the ultimate governing body in each type of big company, but the other key corporate participants are determined by one of the three following forms permitted by the Companies Act (2014).

- From 1890: Company with statutory auditors (Company with Kansayaku Board - a company with a board of statutory auditors (Kansayaku-kai).

- From 2003: A Company with Three Committees (3C) - nomination, audit, and remuneration.

- From 2015: A Company with an Audit and Supervisory Committee (New Governance System).

Companies with statutory auditors have been in existence since 1899 and stem from the first wave of hybridization, while the next two governance structures are much younger as they are the result of the third wave of hybridization. Japanese big corporations can choose and adopt the most appropriate organizational structure (as stipulated by the Companies Act) to suit a company's specific needs. Companies can employ optional approaches, as necessary, to further enhance governance functions (Corporate Governance Code (CG Code), 2018, Principle 4.10). OECD calls it multiple option with hybrid system (OECD, 2019, p. 135).

The Japanese concept of a board is more akin to a senior management committee that meets regularly to make detailed operational decisions, than a body with strategic oversight of the company. The board of directors (the governing body) makes decisions concerning maximisation of the interests of shareholders, and other stakeholders. Under Japanese law, directors and executive officers must perform their duties with the care of a prudent manager, in compliance with all laws and regulations and resolutions of shareholders' meetings, and in a loyal manner.

Corporate Governance Code (2018, General Principle 4) states that Given its fiduciary responsibility and accountability to shareholders, in order to promote sustainable corporate growth and the increase of corporate value over the mid-to long-term and enhance earnings power and capital efficiency, the board should appropriately fulfil its roles and responsibilities, including: setting the broad direction of corporate strategy; establishing an environment where appropriate risk-taking by the senior management is supported; and carrying out effective oversight of directors and the management....from an independent and objective standpoint. Such roles and responsibilities should be equally and appropriately fulfilled regardless of the form of corporate organization (Corporate Governance Code, 2018, Ch.4, P.4).

The board should view the establishment of strategic directions, corporate goals, and an environment that supports appropriate risk-taking by the senior management as major aspects of its role and responsibilities. It should welcome proposals from the management based on healthy entrepreneurship, examine fully and objectively such proposals with the aim of securing accountability and support timely and decisive decision-making by the senior management when approved plans are implemented. The remuneration of the management should include incentives reflecting mid- to long-term business results and potential risks in promoting healthy entrepreneurship. The board should view the effective oversight of the management and directors from an independent and objective standpoint as a major aspect of 
its role and responsibilities. It should appropriately evaluate company performance and reflect the evaluation in its assessment of the senior management; should ensure timely and accurate information disclosure; establish appropriate internal control and risk management systems; deal appropriately with conflicts of interests that may arise between the company and its related parties, including the management and controlling shareholders (Corporate Governance Code, Principle $4.1-4.3$ ).

Where directors are negligent or knowingly fail in performing their duties they are held liable to the company and their shareholders directly for the resulting damages; only when they can prove that they did not fail to exercise their duty of care will they not then be held liable (Companies Act No. 86 of 2005).

The above statements reveal that Japanese regulations (in theory) are compatible with the international requirements concerning boards, their roles, and responsibilities, especially those stated by the OECD Principles of Corporate Governance.

The three forms of Japanese boards allowed under the Companies Act (Revised in 2014) will be now characterised, with respect to hybridization.

\subsection{A company with statutory auditors - a company with a Kansaniaku Board (Kansanyaku $-\boldsymbol{K} A I)$}

After 1896 (first wave of hybridization), the Kansayaku Board was the traditional Japanese structure, a compulsory body in joint-stock companies with no right to appoint outside directors (The Corporate Auditor System in Japan, 2007). In this model certain governance functions were assumed by the kansayaku and the kansayaku board. The annual general meeting of shareholders (AGM) as the highest body in company, had the power to supervise the board of directors. However it was only an irregular arrangement, usually convened at the behest the directors, this led to the Japanese Code instituting the Board of Auditors (a weak counterpart to the German Supervisory Board) to permanently exercise supervision.

The role and importance of boards of directors, and boards of statutory auditors, evolved over time in accordance with the changes in the political and economic environment. These changes were a result of the absorption of patterns and principles that were considered best for improving business management and reflected the hybridization process of the Japanese corporate governance system.

Until 1938the statutory auditor had to be a shareholder of the company, appointed to monitor the activities of the board of directors, and could not be a member of the board. At that time the law required the nomination of one statutory auditor, however shareholders could choose more of them if they so wished. At first statutory auditors did not have to be accountants or even economists. This governance structure functioned without any major changes until the 1950s.

After World War II, the American occupying authorities sought to shape the Japanese system along the lines of the American corporate governance model (Raupach-Sumiya, 2000). Their efforts concerning breaking up Zaibatsu, dismissing top management, introducing a new perspective on business and society were so serious that they impelled the second wave of hybridization of Japanese economy and corporate governance.

The board of directors is the organ of representation which is often linked to the executive body of the state. Its members are elected by the AGM. According to law a board of directors shall consist of three or more persons, however in practice, they often grow to 20 or 30 members, made up almost entirely of internally promoted managers who have risen through the ranks of the company as employees (Miyajima, Aoki 2007; Milhaupt, 2003; West, 2001). In a Company with statutory auditors, directors generally serve as managers of the company. 
They play a dual role - executive and supervisory, and therefore the two-tier board structure is not employed in Japan (Dore, 2000; Yamamura and Streeck, 2003). The traditional board is treated as the decision-making body, not as a CEO supervisor. Its responsibility is to manage the company's business activities and supervise the execution of the duties by each of the directors and executives (Companies Act, 2006 Art.362 \& 4; Tsuboi, 2014). A company in good financial condition manages its affairs under the supervision of a board. In case of financial difficulties, the bank financing the company intervenes by taking rescue or liquidation measures in its best interests (Aoki, Patrick, 1994). The board has the authority to make executive changes as it sees fit.

Companies Act states that joint-stock companies based in Japan must have a representative director who holds the position of the most senior executive in charge of managing a corporation. This is the director with the company's highest authority, appointed by the board from among directors (as other executives). However, a representative director is not considered to be an employee of the company and is unable to receive certain benefits which are accorded to employees. The person holding this position is registered publicly on the official corporate register. The statements of the representative directors are legally binding on the corporation, typically they report to the companys' boards of directors and are responsible for maximizing the value of the business. The representative director monitors the activities of the board of directors and statutory auditors.

Directors incur general responsibility for the management and daily operation of the company. They have the right to sign legal contracts on behalf of the corporation. They are not representatives of shareholders and they monitor the activity of company's boards of directors and statutory auditors. The members of these boards consider themselves to be well-equipped employees of the company, not shareholder agents, therefore the president has great autonomy in countering control by the board of directors (Raupach-Sumiya, 2000). The term of office of a director shall not be longer than two years, but they may be reappointed (Companies Act,2006, art. 332). In the company with statutory auditors, directors and managers are evaluated on their performance and if it is not satisfactory they will not be re-nominated by the board. Now remuneration of directors must be approved at a shareholders' meeting. In practice (Companies Act, 2006, Article 179) most companies approve only a maximum aggregate amount of remuneration for all directors, delegating its decision for individual directors to the board or to the representative director. Pay differentials between board members and ordinary employees are low. Stock options or incentive payments were almost non-existent in Japan until the late 1990s (Kobayashi, 2015).

Directors may be dismissed at any time by the AGM, but in case of the fixed term of office, if they are dismissed before that term without reasonable cause, they may claim damages arising from such dismissal. If a director acts in violation of the law or the articles of association, they are liable for damages to third persons even if they acted in accordance with a resolution of the AGM (Companies Act, 2006, Art.339, (1,2); Art. 429). This provision is not applicable to a director who objected the resolution in the AGM and had given notice to the auditors. A director aware that the company is exposed to serious damage must notify the board of statutory auditors, even if not asked to do so.

Since February 2014, the Companies Act and Securities Listing Regulations oblige listed companies to nominate at least one outside director and provide information on compliance or explain principle. The Corporate Governance Code in 2015 recommended the appointment of two independent directors, while the Code from 2018 (Principle 4.8) had been recommending an appointment of at least two independent directors. However, if a company believes it needs to appoint at least one-third of directors as independent directors, basing it on a broad consideration of factors such as the industry, company size, business characteristics, 
organizational structure and circumstances surrounding the company, it should do so. Companies with a board of statutory auditors are required to nominate four outsiders, i.e. one external director and two external statutory auditors. In addition, only persons with appropriate experience and skills as well as necessary knowledge of finance, accounting, and law should be appointed as kansayaku. In particular, at least one of the appointed kansayaku should be an expert in finance and accounting.

As was explained the supervision of statutory auditors supplements the monitoring functions performed by the board of directors. The Japan Corporate Auditors Association (2012) emphasizes their uniqueness, significance and distinctness of their functions compared to external and internal auditors in the Anglo-American model, emphasising statutory auditors as an important link in the overall structure of Japanese corporate governance. Their mission is different from the mission of the internal auditor or chartered accountant in Anglo-American corporations because their duty is to audit and supervise directors from the point of view of their fiduciary duty and preventing fraud (Ovsiannikov, 2017). Their basic function is to act for the good of the company, by controlling directors' activities and performing financial and business audits (The Corporate Auditor System in Japan, 2007). Business audits involve checking whether directors, while managing companies, comply with the formal legal provisions, regulations, statutes, and perform their fiduciary duties. This is called compliance audit and it does not include checking the correctness of decisions and actions taken by directors but must confirm that they fulfilled their obligations to look after the company's interests (JCAA, 2008). A financial audit concerns financial statements and must be conducted before the annual shareholders' meeting. When reviewing, kansaniaku may check accounts books and relevant company documents, request explanations from the director or accounting adviser (a new, voluntarily legally sanctioned position to increase the credibility of financial documents) (Lee, Allen, 2013). The statutory auditor's report containing the results of the financial and business audits must accompany the notice of the annual shareholders meeting (JCAA, 2008). This report is prepared by the Kansayaku Board, but each statutory auditor has the right to express his own opinion as each kansayaku can fulfil their duties independently. The statutory auditors shall examine the documents submitted to the AGM by the directors and express their opinion on them to the general meeting of shareholders. If these proposals and documents contain material errors or are unlawful, the statutory auditor must submit his objections on them to this body.

The statutory auditors are appointed (dismissed) by a shareholders' meeting separately from directors (by at least $1 / 3$ of the total number of votes), but their nomination depends on the board consisting of managers subordinated to the CEO (Sakamoto, Harima, 2014). Members of the Kansayaku Board have the right to speak on the proposals of candidates for statutory auditors, which the board of directors presents to the general meeting of shareholders for voting (Aronson, 2014).A Board of Statutory Auditors is composed of company auditors who are internally promoted employees of the corporation, having the right to attend directors meetings and receive regular reports from directors, but they do not have the right to vote (Nottage, Wolff, Anderson, 2009, p.131). They act as consultants and do not question the decisions of the board of directors (Kanda, 2000). Because managers monitor the activity of the board of statutory auditors, the latter may not sufficiently protect the interests of shareholders despite their fiduciary responsibilities towards them (Tsuboi, 2014). They hold an important position in the company, but they cannot concurrently serve as directors or managers (Comercial Code, 2006 Art.184). The compensation that statutory auditors receive is fixed by the AGM.

In 1950, during the initial stage of imposed Americanization, Commercial Code provisions weakened the legal status of kansayaku by depriving them of accounting, auditing, 
and supervisory functions, entrusting the board of directors with all responsibility for supervising and controlling managers. The system of statutory auditors was planned to be substituted by the system of external auditors modelled on the American Chartered Public Accountant (CPA), after educating the desired number of professionals (Patrick, 2004). However, the political changes in 1950s caused that US stopped intervening in the Japanese economy and regulatory actions started gradually to restore and strengthen kansayaku powers. They regained the power to conduct business audits and sue directors in 1974. Kansayaku were obliged to approve transactions where there was seen to be conflicts of interest, but this rule no longer exists. The amendment to the Commercial Code in 1981 obliged large companies to have a kansayaku kai, a separate body from the board of directors, which must include at least one full-time kansayaku. These changes significantly improved the strength and independence of statutory auditors. The duties of the board of statutory auditors include the appointment and dismissal of full-time company auditors from among themselves, making decisions regarding the audit policy, the type and method of auditing the state of operations and corporate assets, and other matters regarding the fulfilment of their duties by statutory auditors (Companies Act, 2006).

In 1993 large companies were obliged to nominate at least three statutory auditors, forming a board of statutory auditors, one of which should be an independent (outside director) auditor, on condition that they could not have been a director or employee of that company or of any of its subsidiaries in the last five years (Japan Audit and Supervisory Board Members Association, 2007). In 2009, the Tokyo Stock Exchange (TSE) published a definition of an independent director (referred to the provisions of the American Sarbanes-Oxley Act (2002)) and required listed companies to appoint at least one independent director or one independent statutory auditor. Currently, in accordance with the Companies Act, no fewer than half of Kansayaku Board, must be composed of outside kansayaku, and at least one full-time kansayaku must be appointed. The Corporate Governance Code (Principle 4.4.1) states that the Kansayaku Board should, from the perspective of fully executing its roles and responsibilities, increase its effectiveness through an organizational combination of the independence of the former and the information gathering power of the latter. In addition, the Kansayaku Board should secure cooperation with outside directors so that such directors can strengthen their capacity to collect information without having their independence jeopardized.

Kansanyaku functions also include collecting information necessary for supervision, reporting, consulting, developing proposals for the board of directors, resolving conflicts of interest between managing directors and the auditor. The Commercial Code (Articles 181, 183, 185) states that the auditors may at any time require the directors to make a report of the business or may conduct internal investigations. Kansanyaku is required to report to the board of directors any suspicion of breaking the law, infringements of statutes, or the possibility of their breach by the director and is obliged to prevent the director's actions exposing the company to losses. In a dispute between a company and its director the statutory auditor represents the company and decides whether to sue the director on behalf of the company. Directors may be released from liability by all members of the Kansanyaku Board.

A Statutory auditor, along the lines of the US Audit Committee, is also responsible for monitoring and managing external financial auditing. A large company must appoint an external certified auditor (or audit firm), who is elected by the AGM, but whose candidacy must be approved in advance by the Kansanyaku Board. That Board is also required to establish standards for the appropriate selection of candidates and procedures for the evaluation and verification of their independence, expert knowledge, and auditor remuneration. Statutory auditors should be given adequate time to ensure high quality audits; provide external auditors with access to the senior management, create adequate coordination between external auditors 
and each of the kansanyaku (attend the Kansanyaku Board meetings), the internal audit department and outside directors; and that the company is able to adequately respond to any misconduct, inadequacies or concerns identified by the external auditors (Corporate Governance Code, 2018, Principle 3.2.1 - 3.2.2). An external financial auditor reports to the Kansanyaku Board and board of directors on the audit report. The statutory auditor checks the correctness of the process description and financial audit results, and in case of finding irregularities, they must report it, justifying the assessment. Afterwards the auditor conducts the audit and prepares an appropriate report.

Currently Kansaniaku performs their duties for 4 years (before was it was1 year) and may be re-appointed on the expiray of their term (Commercial Code, Article 180). The Companies Act sets out the conditions for dismissal of kansayaku and directors. The office of an auditor is terminated on a declaration of his bankruptcy or incompetency, but they may be dismissed by shareholders at any time (Lee, Allen, 2013). Auditors neglecting their duties are liable for damages to the company and third persons (Commercial Code Art. 186 and 188).

In order to fulfil their roles and responsibilities, directors and kansayaku should proactively collect information and as necessary, request additional information and verify whether it is provided smoothly. Companies should establish a support structure for directors and kansayaku, providing adequate staff. Directors and kansayaku should understand their roles and responsibilities, as a critical governance body, and should endeavour to acquire and update necessary knowledge and skills during trainings provided and paid for by the company. The board should verify whether such opportunities and support are appropriately provided (Corporate Governance Code, Principle 4.13, 4.14).

Companies with Kansayaku Board (there are 2,553 such companies) must state whether they have outside directors, what their roles and functions are and describe reasons for adopting the current governance structure. (White Paper on Corporate governance, 2019, p.93). In 201982 Companies (3,2\%) with Kansayaku Board reported that they did not have outside directors (White Paper..., 2019, p.93).

The system with the board of statutory auditors is the basic, well-established form of Japanese corporate governance. It worked well when the economy and companies grew rapidly. All stakeholders were being rewarded, mistakes were papered over, and the few firms that fell into distress were speedily dealt with by their Main Bank and the government. Therefore, corporate, and public governance systems were widely trusted and accepted (Teranishi, 2005, s. 234; Aoki, 1990; Aoki, Dore, 1994).

The board of statutory auditors is used by $98 \%$ of public companies, but the reforms have seriously affected companies using this governance structure. It owed its popularity, among others, to the lack of the need to appoint external directors (Eberhart, 2012), but now companies with this supervisory structure must have at least two external statutory auditors and two external directors. Thus, this supervisory body is slowly acquiring some features of the American system while preserving the Japanese traditional ones and reflecting the hybridization process.

\subsection{A company with Three Committees (3C) - the Iinkai system}

Dissatisfaction with the protracted economic slowdown and growing recognition of the thriving US economy, together with criticism of the traditional boards dominated by internal directors, weak boards of statutory auditors, and the growing share of foreign investors in the ownership of Japanese companies, forced METI to start the institutional transformation process and further corporate governance reforms (Milhaupt, 2003; Itami, 2005, s. 4; Shishido, 2007). One of the results of the reforms was a new governance structure conditional on consent of 
shareholders and making an appropriate entry in the company's statute. Since April 2003 the amendments to the Companies Act (2002) have given large Japanese corporations the choice between the traditional auditor system and a committee system similar to that adopted by listed US firms, namely the Company with Three Committees ( $3 C)$ - audit, nomination and remuneration (Companies Act, 2005, Art. 390.1).

A Company with Three Committees is a good example of the influence of American law on Japanese legislation, and of hybridization processes aimed at improving corporate governance. It represents a new shareholder-oriented system modeled on the US SarbanesOxley Act of 2002, and on the innovative reforms carried out at Sony. Implementation of this system was promoted and supervised by the American Chamber of Commerce in Japan.

A $3 C$ company must have a board of directors and at least one accounting auditor, but there is no need to involve statutory auditors. The three committees - are subordinated to the board of directors. Shareholders elect directors, from candidates nominated by the nomination committee, and the members of the newly chosen board of directors, elect the members of the three committees from amongst themselves.

Japanese Corporate Governance Code (2018) recommends that companies should make effective use of independent directors, taking into consideration the following expectations with respect to their roles and responsibilities: advice on business policies and business improvement based on their knowledge and experience, promote sustainable corporate growth and increase of corporate value, monitor the management through important decision-making at board level including the appointment and dismissal of senior management, and monitor conflicts of interest between the company and the management or controlling shareholders; appropriately represent the views of minority shareholders and other stakeholders in the boardroom from a standpoint independent of the management and controlling shareholders (Principle 4.6 \& 4.7 ).

Independent directors should fulfil their roles and responsibilities with the aim of contributing to sustainable growth of companies and increasing corporate value over the midto long-term. The board should be well balanced in knowledge, experience and skills in order to fulfil its role and responsibilities, and it should be constituted in such a manner as to achieve diversity in both gender and international experience and appropriate size. The board should also endeavour to improve its function by analysing and evaluating the effectiveness of the board (Principle 4.11). Boards should establish and disclose independence standards, taking into consideration the independence criteria set by securities exchanges. The board should endeavour to select independent director candidates who are expected to contribute to frank, active and constructive discussions at board meetings (Corporate Governance Code, Principle 4.9). A manager, without the permission of the company, may not become a director, executive officer or operative of any other company (Companies Act, art.12.1. IV).

The audit committee is obligated to audit the execution of their duties by directors, executive officers, accounting advisors, also the financial statements of the company, and determine the contents of proposals regarding the election, dismissal and refusal of re-election of accounting auditors submitted at a shareholders meeting. Audit committee members may at any time, request reports on the execution of their duties from executive officers and employees including managers or investigate the status of the operations and financial status of the company and its subsidiaries. If they find that executive officers or directors engage or are likely to engage in misconduct, or that there is evidence of violation of laws and regulations or of the articles of incorporation or grossly improper conduct, they must report such matters to the board of directors without delay. Its members may not concurrently act as an executive officer or executive director of a $3 C$ Company or its subsidiary company, or as an accounting advisor or employee. This committee performs a role similar to that of the board of statutory auditors monitors and certifies financial information being provided to shareholders, the legality of 
company operations, audits the activities of managers, directors and accounting advisors, prepares audit reports and makes decisions regarding the proposal to appoint and dismiss external auditors submitted to the AGM (Companies Act, 2006, Art. 404-406).

The remunerations committee (Companies Act 2006, Art.409) decides on the remuneration for each manager and director, including the president, as well as accounting directors and advisors in accordance with the remuneration policy prescribed by the committee. The approval of a shareholders' meeting is not required. The nomination committee determines proposals to be submitted at the shareholders' meeting regarding the appointment and dismissal of directors and appoints the president and managers. Decisions of these committees cannot be rejected either by the board of directors and managers, or by the president and CEO.

The board's primary functions are stated by the Companies Act as taking certain fundamental decisions, setting basic company policy and matters regarding the interrelationship and hierarchy of command between executive officers, appointing and monitoring executive officers as a separate group whose role and duties are legally defined, developing systems necessary to ensure that the execution of duties complies with laws, regulations and the articles of incorporation, as well as systems necessary to ensure the proper operations of a company, a group and its subsidiary companies. If executive officers detect any evidence likely to be detrimental to the operations of $\mathrm{t}$ the $3 C$ Company they must immediately report such facts to the audit committee members (Companies Act, 2006 Art. 146.1; 419.1).

The board of directors appoints and supervises (one or more) executive officers and representative director(s) who manage and operate the company daily for the period of 1 year (may be re-elected). The board may delegate a large proportion of its powers of making management decisions to managers. This will allow this body to focus on supervising the performance of the managers' duties, not on making management decisions. Thus, the $3 C$ system companies are managed not by directors, but by managers appointed by the board of directors. Executives are evaluated on their performance, and if it is not satisfactory, they will not again be nominated or re-elected by the board. They may be dismissed at any time by a resolution of the board (Companies Act, 2006 Art. 362.1; 403.1).

Proponents of this model believe that it should create competitiveness between the two governance systems, giving the market the opportunity to choose more effectively, which of them will effect improvement in corporate governance (Nottage, Wolff, 2005). However, it must be remembered that it is also a hybrid governance structure having some weaknesses. One of the most serious among them is that some executive officers (typically at least one and less than half of all executive officers) serve as directors at the same time on both bodies.

The 3C Board created on the pattern of the American Sarbanes-Oxley Act (2002) is a challenge for Japanese corporations as only 71 companies (2\%) had adopted this structure as of December 31, 2018 (Nishimura, Asahi, 2020).

\subsection{Company with an audit and supervisory committee - (Kansa-Kantoku Iinkai)}

A Company with an Audit \& Supervisory Committee, also called the New Governance System (proposed in 2012 by the Legislative Council of the Ministry of Justice as part of the amendment to the Companies Act) has become effective for large Japanese companies since May 1, 2015. This new supervisory structure is seen as combining Japanese tradition and American practice, an intermediate solution (compromise) between the board of statutory auditors and the board with 3 committees (Masuda, Yoshida, 2016). The choice offered by the Ministry of Economy, Trade, and Industry (METI) and the Ministry of Justice (MOJ) is in fact a compromise between the two disputing parties representing different views on Japanese 
corporate governance development. Goto (2013) says that this system should be understood as a monitoring model constituting a correction of the company with the three committees.

The provisions on corporate governance have been aimed at strengthening the supervision exercised by the board of directors, granting greater powers to statutory auditors in the selection and dismissal of auditors, strengthening supervision over raising of funds, and facilitating companies to introduce external directors to board of directors. The new system also provides greater transparency in the separation of operational management and supervision, assigning an external role to corporate executives.

A company having the Audit and Supervisory Committee is not required to create nomination and remuneration committees, nor to have external statutory auditors. It should have at least three members, most of whom must be external directors. The board of directors nominates director candidates, but to strengthen independence, the members of the Audit and Supervisory Committee are elected (removed) by a resolution of the general meeting of shareholders, separately from other directors. The term of office for a director who is a member of this Committee continues until the end of the annual shareholders' meeting for the last fiscal year ending within two years after the director's election, while the term of office of other directors lasts one year. Their dismissal requires a clear majority of votes of authorized shareholders. The members of the Audit and Supervisory Committee are directors entitled to vote at board meetings. Requirements for external directors and auditors have been specified, and it is recommended that large public companies have at least two external independent directors (according to TSE requirements - at least one external director or statutory auditor). In both cases, companies not complying with this recommendation, in accordance with the principle of comply or explain, are required to provide comprehensive justification for that choice. The advantage of a company with the Audit and Supervisory Committee is that it has at least two votes from external directors on the board of directors that can be used to dismiss a CEO who is failing in his obligations to shareholders. It allows for lowering the costs of supervision by reducing the number of required external directors in comparison to the company with statutory auditors.

According to the Companies Act (2006 art. 399- 2.2; 13.1) the Audit and Supervisory Committee performs the following duties: decides on basic management policy, on matters prescribed by Ministry of Justice Order as those necessary for the execution of duties of this particular governance structure; the development of systems necessary to ensure that the execution of duties by the directors complies with the laws and regulations and the articles of incorporation, and other systems prescribed by Ministry of Justice Order as systems necessary to ensure the correctness of operations of a stock company and of operations of a group of enterprises constituting the stock company and its subsidiary companies.

The Audit and Supervisory Committee not only audits the company's operations (protects the legitimacy of the company's business), but also oversees the effectiveness of this activity. It is also obliged to audit the results of the company's management, including the representing director. Furthermore, directors of a company who are members of this Committee cannot be simultaneously managing or representing directors, or other directors or employees of that company or its subsidiaries, this also precludes acting as accounting advisers to the company or its subsidiaries. The Committee is empowered with a broader audit authority than the statutory auditors in a company with statutory auditors and is authorised to state its opinion on the election, dismissal and remuneration of directors who are not members of the Audit and Supervisory Committee at the shareholders' meetings. It is expected that this committee, mostly composed of external directors, will carry out audits more effectively than the board of statutory auditors. As companies with 3-committees, an Audit and Supervisory Committee, must have an accounting auditor. Both propose candidates for the election of an accounting auditor. 
Directors are evaluated on their performance, and if it is not satisfactory, they will not be nominated or re-elected, by the board of directors. This Committee is not entitled to select managers or determine their remuneration, although it suggests remuneration of directors not being its members to the shareholders meetings but is obliged to supervise them. The AGM sets the amount of remuneration for members of this Committee who may divide it between themselves at their own discretion. This strengthens the position of its members and makes them independent of management decisions.

The board of directors designates the representing director (CEO) from among nonmembers of the committee. Its responsibilities include establishing the main management policy principles, building an internal control system, and overseeing the activities and results of other directors. These obligations correspond to those implemented by boards in companies with three committees but are broader than in companies with a board of statutory auditors, which are not obliged by law to set management policy (Goto, 2013).

The committee audits and supervises the results of directors' activities using the internal control system. Any member of this Committee may audit and supervise the company. During the AGM, its members have the right to express opinions regarding the appointment and remuneration of the directors of the company. In addition, Audit and Supervisory Committee members may request directors, accounting advisors, managers, and other employees to report on matters related to the execution of their duties, or may investigate the operations and financial status of the company (and its subsidiary companies) at any time. During the meeting of shareholders, they are obliged to report any violations of law, errors or insignificant matters contained in the agenda or other documents submitted to this body (Companies Act, Art. 3993.1). These powers strengthen the Committee's ability to perform effective auditing and oversight. The possibility of transferring many matters belonging to the board of directors to managing directors also contributes to this in the same way as it does in companies with 3committees. In a sense, it is a substitute for the nomination and remuneration committees functioning in the $3 \mathrm{C}$ companies.

Directors, executive officers, or employees (including managers) of the parent company or any of its subsidiaries, and close relatives of directors and executives of the company, are no longer eligible to be outside directors. However, in practice, directors of companies with a business relationship often serve as outside directors of a company. A listed company must disclose its independent officers' details in its corporate governance report. If an independent officer has certain relationships with the company (for example, is a main business partner, a consultant, or a major shareholder) this relationship must be disclosed upon the designation of the individual as an independent officer. In addition, the Corporate Governance Code provides that the board of a listed company should establish and disclose its own standards of independence for independent directors. The Companies Act amended in 2014 has introduced a more stringent disclosure requirement than the normal "comply or explain" approach, requiring companies with no outside director to explain in the annual shareholders meeting the reason why appointing one is inappropriate, as well as to explain that reason in the annual report and the proxy materials of the shareholder meetings (OECD, 2019, p.118).

Combining the traditional Japanese model - the company with statutory auditors, and some features of the 3C Company within the Audit and Supervisory Committee is evidence of hybridization in the Japanese corporate governance system. In July 2014 approximately 65\% of TSE-listed companies had outside directors, in 2019 over $90 \%$. 


\section{Discussion}

The direction of corporate governance reform in Japan involves experimenting with hybridization processes by adapting new concepts to local circumstances. In justifying that hybridization rather than convergence resulted in an improvement of Japanese corporate governance, and trying to find out why the system has been evolving in this way, it is worth recalling West (2001) saying that "fifty years of Japanese interaction and competition with US have not led to statutory convergence, it concerned only some limited issues". Traditional practices are hard to change because Japanese culture has a great impact on social and business relations (West, 2019).

The reasons for hybridization vary, but it seems that the outcomes are always beneficial for the economy as it helps to solve serious problems so enabling its modernization and development. These changes are always revolutionary for very traditional Japan, and lead to the creation of a unique (hybrid) Japanese model of corporate governance. The board of directors is a good example of the process of hybridization in practice.

Japanese corporations should choose and adopt the most appropriate organizational structures to further enhance governance functions. The assessment of the three forms of Japanese boards allowed under the Companies Act (2014) with respect to hybridization enables us to identify the pros and cons of each of them in the aspect of corporate governance modernization and internationalization. Companys with statutory auditors have been in existence since 1899 and stem from the first wave of hybridization. In this governance structure monitoring, performed by the board of directors, is supplemented by the supervision of statutory auditors. Their duty is to audit and supervise directors from the point of view of their fiduciary duty and preventing fraud (Ovsiannikov, 2017). The board of statutory auditors is a body like the US audit committee, but separate from the board of directors, as no corporate auditor can be a member of the board (Takei, 2012). The joint oversight obligation results in compatibility with the oversight responsibilities of the corporate governance continental model (Takei, 2012). This model has three main strengths (Inagami, Whittaker, 2005) such as long-term vision of the management who generally work for the same company for a long time, relatively small transaction costs because of corporate monitoring by banks and relatively flexible restructuring of a corporation because the interests of various stakeholders can easily be considered.

Shortcomings include lack of transparency due to extensive implicit contracts involved in transactions. Managers can abuse their discretionary power by, instituting trade friction with global international businesses, drastic and speedy corporate restructuring because various implicit contracts are likely to hinder the process (Okabe, 2009). Kansayaku and the board of directors are required to jointly monitor and control the company, but are considered inefficient in this respect (Takahashi, Madoka, 2005). A board of statutory auditors is in theory supposed to monitor the board of directors but, in practice, the kansayaku has a vague mandate and virtually no power, as they have no right to appoint or remove directors and do not represent shareholder or employee interests. Since they are nominated by the board, it is not clear who supervises managers (Ahmadjian, 2008; Chizema, Shinozawa, 2012; Kansaku, Takei, 2012). (One can take the view that the corporate auditor's system works in practice in the field of monitoring and contributes to its increase.) Like members of the board of directors, statutory auditors are often former employees of the company with limited access to internal information, and are chosen by the chairman (Jackson, Miyajima, 2007; Ekhart, 2012). Managers decide about their selection and dismissal, and they have poor employee support and status, because they are often perceived as senior employees who failed to become directors (Ahmadjian, 2003). This system does not work in the light of agency theory, because statutory auditors do not question wrong decisions made by managers as they have no incentive to look after the 
interests of shareholders, especially if creates conflict with managers (Shishido, 2007). They are required to attend board meetings, but without voting rights, so they are unable to effectively supervise directors (Jackson, Miyajima, 2007; Goto, 2013). For this reason, managers pay little importance to the objections of corporate auditors. The kansanyaku only gives permission for or has a veto on the selection of the outside auditor. The board of statutory auditors is very popular and used by $98 \%$ of public companies, but the reforms have seriously affected companies using that structure. It owed it popularity to the lack of the need to appoint external directors (Eberhart, 2012), but now companies with this supervisory structure must have at least two external statutory auditors and two external directors. Thus, the implementation of key US legal regulations, which have been growing since the beginning of the1990s, led to the creation of the American model of company law (A-model) and a process called Internal Americanization (Shishido, 2007, p. 328). US-style governance gives top priority to shareholders and emphasizes a firm's duty to maximize shareholder value. Some authors believe that the appropriate institutional framework for introducing the shareholder model has not yet developed in Japan, and changes in corporate governance, especially in ownership structure, cannot be interpreted as a departure from the stakeholder model. Family ownership of enterprises is not conducive to focusing on maximizing shareholder value and the Americanization of Japanese corporate governance practices (Miyajima, 2014, Ovsiannikov, 2017).

The second governance structure, the $3 \mathrm{C}$ audit committee, has been implemented into Japanese company law since 2004. It functions more like the Audit Committee of a US company. It is more powerful in comparison to kansayaku, as the members of that committee are board directors and can vote. Unlike Kansayaku Board members, 3C audit committee members do not automatically enjoy an individual right to investigate. Like kansayaku, the 3C audit committee must report to the board about past or likely violations of law by directors or executive officers. The $3 C$ audit committee is comprised of directors, a majority of whom need be outside directors, who should be the objective supervisors of shareholder interests. A major weakness with the 3 -Committees system is that an inside director, usually a former executive director, may chair the committee.

In the Iinkai companies, as in the kansayaku companies, management power remains in the hands of the president and the managing directors subordinated to him, thus the board is still the supervisor of the company's management activities. In companies with 3C, managers have more freedom compared to the system of statutory auditors, the board of directors is essentially a board, provides separation of monitoring and management, and greater transparency (Chizema, Shinozawa, 2012). Although the indicators characterizing the participation of external directors in Japanese companies still show significantly lower values compared to other countries, but they have a growing tendency to embrace change. Even though external directors do not constitute a majority in the 3-Committees, the reputation resulting from their participation increases the importance of the corporate control market (Ovsiannikow, 2017). The implementation of the American 3-Committee has decreased the risk of doing business for foreign investors, as it is quite difficult for them to understand and use the nuances of Japanese law (it is very difficult to become a corporate lawyer in Japan).

Since the key functions - remuneration of managers, appointment of managers and financial monitoring - are supervised by committees with external directors who are not subject to the president, the $3 C$ system is said to be more trustworthy. It provides more transparent and effective monitoring and has advantages from the perspective of shareholders (Goto, 2013). The participation of external directors in the nomination, audit and remuneration committee is associated with a greater detecting of inappropriate behavior and of applying sanctions. By choosing a new system in which managers submit books and other documents to external 
directors for audit the company signals its readiness to be more transparent and subject to external evaluation, as well as closer linking its interests with those of shareholders. This system is therefore more transparent and allows lower agency costs by reducing information asymmetry (Shishido, 2001, p.321). Closer correlation of the interests of managers and shareholders may result in better valuation as the $3 C$ companies are priced higher in comparison to those using the traditional kansayaku governance system.

It was mentioned already that the $3 C$ Board created on the pattern of the American Sarbanes-Oxley Act (2002) is a challenge for Japanese corporations as only 71 companies (2\%) had adopted this structure as of December 31, 2018 (Nishimura, Asahi, 2020) It is less popular than the other two structures in number. The specific reasons for adopting the Company with 3-Committees model are: the comparative advantage over a Company with Kansayaku Board because of the clear separation of oversight and business execution, speeding up the decisionmaking process, strengthening of the oversight function with outside directors (White Paper on Corporate Governance, 2019, p. 93). However, it is necessary to improve the $3 \mathrm{C}$ board, by clarifying the definition of the external director, prohibiting the simultaneous performance of the functions of external director, and the managing director in companies with the comitology system (Tsuboi, 2012). Such improvements may affect the greater acceptance of this American structure by Japanese corporations.

The US's corporate governance ideology and values are not popular due to the reluctance of Japanese businessmen to directly monitor companies and to introduce managers' responsibilities towards shareholders (Ahmadjian, 2017, p.125-150). A significant obstacle in the implementation of this "American" board is that presidents of companies do not want to change their internal governance systems to those requiring nomination of external directors, action-based incentive systems and an increase in transparency and disclosure. They do not want to give up their power to appoint their successors, which interferes with the duties of the nomination committee, and the control of remuneration, which falls within the remit of the remuneration committee. Separation of supervision and management, implying objectivity in assessing managers' performance, is not compatible with the Japanese idea of internalism (Itami, 2005, p. 4). The idea to impose a mandatory requirement for outside directors encountered stiff resistance from domestic industry groups. Common charges against this model are that outside directors are not well suited to perform a useful role in highly relational Japanese corporate affairs, and that finding suitable outside directors will be very difficult given the lack of experience with the practice (Nishimura, Asahi, 2020). As was stressed, the weaknesses of the 3C board include the lack of a clear definition of external director because in these companies, external directors are often nominated by the CEO. Consequently, even if the director (auditor) is formally external, he still feels grateful to the company (CEO) for choice and trust (Buchanan, 2007). Directors from parent companies and major trading partners are considered to be independent. They are external directors as defined by the Companies Act, but do not meet the independence criteria set by the Tokyo Stock Exchange rules. Only a small number of companies that have chosen the 3-Committees system have managed to separate monitoring from management, because usually the CEO is a member of the nomination and remuneration committees (agency conflict). The law allows independent directors to perform managing functions. Also, no Japanese manager has sufficient motivation to overthrow the system of statutory auditors and use the $3 \mathrm{C}$ system due to costs, working time, loss of decisionmaking independence. The opponents of the $3 \mathrm{C}$ system argue that it will harm the permanent life-time employment system, thus destroying one of the essential strengths of Japanese management. (Aoki, Jackson, Miyajima, 2017, p. 321-2). Proponents of this model believe that it should create the competitiveness of the two governance systems, giving the market the 
opportunity to choose more efficiently, which will affect the improvement of corporate governance (Nottage, Wolff, 2005).

The 3C audit committee of a Japanese company functions more like the Audit Committee of a US company. It is more powerful in comparison to kansayaku, as the members of that committee are board directors and can vote. They take direct charge of hiring or firing the outside auditor, but do not determine the exact fee and terms of the contract with the outside audit firm, as that is considered an "execution" matter for management. The kansanyaku only gives permission or has a veto right about selection of the outside auditor. Unlike Kansayaku Board members, 3C audit committee members do not automatically enjoy an individual right to investigate. The committee can demand information but, if something needs further investigation, it must assign one of its members to play the role of the lead investigator. Like kansayaku, the 3C audit committee must report to the board about past or likely violations of law by directors or executive officers (who bear fiduciary duties) and can demand a court injunction to force them to cease actions. The $3 C$ audit committee is comprised of directors, of whom only a majority need be outside directors who should be the objective supervisors of shareholder interests. This means that one or more inside directors may serve on the $3 \mathrm{C}$ audit committee only if they do not number half or more of its members. Some argue that boards with a committee system do not have many advantages over the system of statutory auditors. Companies using the $3 C$ system do not show rapid changes in performance. Western solutions do not imply results that differ from those obtained by using a traditional model (Corporate Governance in the 21st Century, 2009, s.153-4). It is not popular as only $2 \%$ of companies had adopted this structure as of December 31, 2018 (Nishimura, Asahi, 2020). However Shishido (2007) notices that although the new board is not compatible with Japanese corporate culture, the basic advantages of the Iinkai system, such as external directors and separation of managers from board members, are increasingly voluntarily implemented by entities faithful to the traditional system of statutory auditors with the desire to improve reputation on the market. There is a continuous increase in the legal protection of minority shareholder interests and the increasing recognition of market control.

A Company with an Audit \& Supervisory Committee is the latest governance structure, combining the traditional Japanese model - the company with statutory auditors, and some features of the $3 C$ Company and is evidence of hybridization in the Japanese corporate governance system.

The advantages of the Audit and Supervisory Committee over a Company with Kansayaku Board concern speeding up the decision-making process, strengthening the oversight function with outside directors, increasing the transparency of management, gaining support from foreign investors, overviewing measures being considered to enhance governance functions, and the roles and functions of outside directors, and increasing the ability to resolve existing conflicts of interest (White Paper..2019, p.93). Suspicion of neglecting obligations towards a company, in a situation where the director conducts a transaction with a conflict of interest (Companies Act, Art. 423 \& 3) will not be justified, if the audit and oversight committee has previously approved such a transaction (Masuda, Yoshida, 2016).

Therefore, taking into consideration its popularity, it may be assumed that this new supervisory structure is better suited to solving corporate governance problems than companies with the two other governance structures. There is, however, some skepticism about whether this new, non-mandatory supervisory structure will really strengthen corporate governance compared to earlier forms, because the members of the Audit and Supervisory Committee are also members of the company's board of directors. The Asian Corporate Governance Association (ACGA, 2019) has expressed doubts that the Committee has established a stronger system of supervision over management, because the authorities and composition of this 
Committee are similar to those of the 3C's Audit Committee, which has fundamental weaknesses, as it does not have to be chaired by an independent director and that inside directors (e.g. a senior manager who has recently stepped down) can sit on it. Some argue that the Audit and Supervisory Committee system was proposed in order to avoid having a completely independent nomination committee.

The analysis has showed that each of these structures has advantages and disadvantages. The innovations introduced are adapted to the Japanese corporate culture, acquiring a unique character. The fascination with the American model has weakened, as the recent financial crisis has shown that it too has some serious weaknesses.

The analysis reveals that hybridization is important in improving Japanese corporate governance and responding to the problems Japan has been suffering since the beginning of XXI century. Despite all the changes towards Internal Americanization and pressure from foreign investors, there is still a sharp difference between the Japanese and the American system of corporate governance. The strong resistance to Americanization makes regulation convergence impossible. Therefore, hybridization is becoming the only solution to combining the benefits of the two models. This process may be observed when considering the board of directors' structures that Japanese big companies can choose.

\section{Conclusions}

This paper argues that hybridization is a process that has been going on for decades in Japan and has significantly contributed to improving Japanese corporate governance, and that the regulations regarding the board of directors are a good example of this process. The research question "why hybridization rather than convergence has resulted in an improvement of Japanese corporate governance" is answered in 3 stages. The first one, aims at showing that Japan's corporate governance system responded to exogenous shocks. We have distinguished three such shocks leading to the creation of the three corporate governance models known as the pre-war Anglo-Saxon capitalism system, the post-war system of prosperity capitalism, and the current market-oriented system. Those three main waves of hybridization led to the creation of three supervisory structures - the Company with statutory auditors (Company with Kansayaku Board), the company with Three Committees and the company with an Audit and Supervisory Committee. The analysis of these structures, as evidence of the hybridization process was the second stage of the research. The reasons (consequences) for hybridization process were pointed out in the third stage.

We argue that the Japanese corporate governance system may be characterised as a corporate and employee-oriented system, with special corporate finance practices and ownership structure, lack of independence on boards dominated by insiders with operating responsibilities, the absence of sufficient internal control and significant resistance to Americanization. The growth and role of independent directors and audit committees are strong "on paper", but board culture and practices remain largely the same in many firms. The CEOs have usually unfettered authority in companies. Japanese managers have a very strong position, even compared to US managers, and regulatory enforcement outcomes are limited and domestic investors tend to be supportive of them. Many managers have a visceral resistance to the idea of placing shareholders above other stakeholders. There are insufficient incentives for managers to introduce new, US or international solutions, as their remuneration is not high in comparison to the US and Europe, and it is not linked to shareholder value creation. People still have a sense of loyalty to their predecessor and seniors, and will go to great lengths to protect them, which is sometimes difficult to reconcile with legal obligations. Outside directors are unpopular, due to the aversion of Japanese businessmen to direct, external monitoring of enterprises and the 
introduction of managerial responsibility towards shareholders. Disclosures and transparency are frequently insufficient, the depth and quality of corporate reporting has significant gaps, too many regulations are soft, and the comply and explain principle is too often used. There is a greater gap between shareholders-friendly laws and the reality of corporate governance than in other countries. Japanese regulators are not doing enough to improve minority shareholders' rights. Corporate governance rules and shareholder rights remain weak in many areas. There are few active asset managers. Companies are still protected from mergers and acquisitions. These specific features of Japanese corporate governance appear to suggest that attempts to fully internationalize Japanese corporate governance are not enough to overcome traditional stakeholder pressures and existing practices, and so have not been fully successful.

Our analysis reveals that the Japanese corporate governance system has changed significantly in recent years. It proves that the internal governance of Japanese corporations has evolved recently towards an Anglo-American style in terms of board structure, management incentives, and the separation between management and monitoring, although these changes are rather slow and small in magnitude. There has been a significant change in the attitude of Japanese managers towards shareholders, who are starting to be treated as important stakeholders. Managers have been inspired to increase the competitiveness of Japanese firms on international markets. Some companies, even voluntarily, are introducing an executive officer and committee systems providing greater separation of management and supervisory functions, boards' diversity, including gender and international experience, reducing the number of directors, and ensuring the supervisory function and effectiveness of their boards. Outside, independent directors have been brought into internal boards of directors, and even if they are not truly independent under the Western requirements, they are a great innovation for the Japanese traditional system. The policy of not employing former top directors after their retirement and evaluating the lifetime employment system has been started. The ideas of the majority of the external directors in the committees, the importance of disclosures, and the leading role of the capital market and shareholder orientation are gaining more and more followers, scandals and social issues have led to increasing recognition of the need for transparency and accountability. It is compulsory to provide an overview of the system of corporate governance used and disclose the reasons why it was adopted. Companies must report governance matters using the comply or explain principle. Whistle blowing has been introduced and companies are required to establish an appropriate framework for it. The requirements regarding auditors have changed, and it is now obvious that the role of auditor requires experience, knowledge and expertise in finance, and accounting. The remuneration of directors and auditors is determined by the AGM and is tied to performance. These modifications reflect changes in the business environment and society. The new developments are proving that hybridization is happening and changing Japanese corporate governance and its competitiveness on international markets.

We argue that despite the Internal Americanization and pressures from foreign investors, there is still a sharp difference between the Japanese and the American system of corporate governance. The strong resistance to Americanization (e.g. Keidanren) makes convergence impossible. Hybridization is becoming the only solution to problems concerning modernization of corporate governance, by adapting the new solutions to national circumstances. This process may be observed while considering the board of directors' structures that Japanese companies can now choose. The hybrids in the form of the board structures are combining Japanese traditions and international requirements.

However, the opponents of US-style corporate governance reforms are very powerful and openly demand that Japanese companies preserve a unique Japanese system. Japan's corporate culture largely continues to be one of seeking consensus and avoiding confrontation 
and the implementation of the comply or explain principle facilitates achieving this aim. On one hand, implementing the new governance structures using this principle is more convenient for the government than enforcing them as hard law. In this way the innovative regulations may raise less controversy and objections and may be more easily accepted by all the stakeholders as companies (directors) gain more time to analyse and to adopt to the new possibilities. In fact, by using the comply and explain principle the corporate governance decisions are being left to companies. On the other hand, the soft method of introducing modernizations enables the preservation of the old structures and may indicate the government's unwillingness to make drastic changes in regulations concerning corporate governance. Such an approach also allows the government to signal to foreign investors that it is ready to improve the system by eliminating obstacles for the flow of international capital but is prudent in imposing them, not wanting to cause conflicts. In this way the requirements of foreign investors and supporters of the traditional Japanese model are combined. Thus, hybridization is reducing conflicts of interests between the state and business, directors and other stakeholders, foreign and local investors, tradition and modernization and therefore is more beneficial in comparison to convergence.

\section{Implications}

The presented analysis is rather general and there is a need for a deeper exploration of the problems under consideration. There are three possible directions of further research. The first one should concentrate on a thorough analysis of the extent and scope of the hybridization of Japanese corporate governance. This will require a precise description of which US or international laws have been implemented, in which areas, when, and to what extent. The second possibility is to assess real hybridization and its reasons. It may be done by pointing out which corporate governance structures have undergone changes and to what extent the hybridization or convergence is taking place, and what are the main benefits, and weaknesses of them. It will require the identification of Japanese and US (international) features in the governance structures and mechanisms. The third direction of exploration is to find out (using a questionnaire) the attitude and preferences of Japanese managers with respect to the mechanisms and structures of corporate governance. This will be useful in predicting the preservation of the old model or the further development of the new governance model, particularly as Japanese business circles are working on some specific solutions in that area.

\section{References}

Aoki, M., Patrick, H. T. (1994). The Japanese main bank system: its relevance for developing and transforming economies. Oxford [England], New York: Oxford University Press.

Aoki, M. (1990). Toward an Economic Model of the Japanese Firm. Journal of Economic Literature Vol.28(1), 1-27.

Aoki, M., Dore, R. P. (1994). The Japanese firm: the sources of competitive strength. Oxford [England]; New York: Oxford University Press.

Ahmadjian, C.L. (2007). Foreign investment and corporate governance in Japan, in: Corporate governance in Japan. Institutional change and organizational diversity. (eds) M. Aoki, G. Jackson, H. Miyajima. Oxford, Oxford University Press.

Ahmadjian C.L. (2008). Japan's Evolving Corporate Governance System Is There a New Model of Japanese Management? APAN SPOTLIGHT, May / June. https://www.jef.or.jp/journal/pdf/159th_cover02.pdf. 
Ahmadjian, C. L., Okumura, A. (2011). Corporate governance in Japan, in: Handbook on International Corporate Governance (ed.) C. Mallin, Edward Elgar, Cheltenham, UK.

Allen F., Zhao M. (2007). The Corporate Governance Model of Japan: Shareholders are not Rulers. Franklin Allen University of Pennsylvania and Bentley College, May, 1-17. http://finance.wharton.upenn.edu/ allenf/download/Vita/Japan-Corporate-

Governance.pdf.

Aronson, B. E. (2014). Fundamental Issues and Recent Trends in Japanese Corporate Governance Reform: A Comparative Perspective. Hastings Business Law Journal, June 10. https://ssrn.com/abstract=2448076.

Augilera R. V., Jackson, G. (2002). Hybridization and Heterogeneity Across National Models of Corporate Governance. Economic Sociology Vol3(2), 17-26.

https://www.researchgate.net/publication/228794551_Hybridization_and_Heterogeneity_Acr oss_National_Models_of_Corporate_Governance/citation/download.

Aguilera R.V., Jackson G. (2010). Comparative and International Corporate Governance. The Academy of Management Annals Vol 4, No 1.

Aguilera R.V., Desender K.A., Lopez-Puertas, Lamy M., Ho Lee J. (2017). The governance impact of a changing investor landscape. Journal of International Business Studies No 48, 195-221.

Aguilera R.V., Jackson G. (2018). Corporate Governance -Business key messages. The Business and Industry Advisory Committee to the OECD, April. http://biac.org/wpcontent/uploads/2018/04/FIN-2018-04-10-Corporate-Governance-Strategy-Paper16.pdf.

Bebchuk L.A., Roe M.J. (2004). A theory of Path Dependence in Corporate Governance and Ownership, in: Convergence and Persistence of Corporate Governance Systems. (eds) Gordon J., Roe M. Cambridge University Press.Cambridge. https://www.researchgate.net/deref/http\%3A\%2F\%2Fdx.doi.org\%2F10.1017\%2FCBO9 780511665905

Bird A. (2005). Encyclopedia of Japanese Business and Management. Routledge.

Braendle U. C., Noll J. (2006). On the Convergence of National Corporate Governance Systems. The Journal of the Interdisciplinary Economics, 17(1), 83-97. https://journals.sagepub.com/doi/abs/10.1177/02601079X06001700105

Branson D.M. (2001). The Very Uncertain Prospect of Global Convergence in Corporate

Governance. Cornell International Law Journal, Vol.34 (2), 322-362. https://scholarship.law.cornell.edu/cilj/vol34/iss2/2

Braucher, R. (1961). Commercial Law in Japan and America. American Bar Association Journal Vol.47( 2), 150-155. www.jstor.org/stable/25721471

Carney M, Estrin S., Liang Z., Shapiro D. (2018). National Institutional Systems, Foreign Ownership and Firm Performance: The Case of Understudied Countries. Journal of World Business. Elsevier, 54(4), 244-257 https://doi.org/10.1016/j.jwb.2018.03.003

Chizema A., Shinozawa Y. (2012). The 'Company with Committees': Change or Continuity in Japanese Corporate Governance? Journal of Management Studies, 49 (1), 77-101.

Commercial Code. (2018). Act No. 48 of March 9, 1899 amended Act No.29 of 25 May 2018.https://www.loc.gov/law/foreign-news/article/japan-commercial-code-amendedlanguage-modernized/.

Companies Act. (2006). Act No. 86. Retrieved February 14.2020 http:///www.japaneselawtranslation.go.jp/law/detail/?id=2035\&vm=04\&re=02

Corporate Governance in Japan. (2017). (eds) Aoki M., Jackson G., Miyaajima H. Edward Elgar (Cambridge University Press), Cambridge.

Corporate Governance in the 21st Century: Japan's Gradual Transformation. (2009). (eds) Nottage L., Wolff K., Anderson Edward Elgar Publishing. 
Corporate Governance Watch. (2018). Report by the Asian Corporate Governance Association and CLSA. file:// D:/Users/wzr/Downloads/CG\%20Watch\%202018.pdf

Denis D. K., McConnell J. J. (2003). International Corporate Governance. The Journal of Financial and Quantitative Analysis, 38 (1), 87-110. March. https://www.jstor.org/stable/4126762

Dore R. P. (2000). Stock Market Capitalism: Welfare Capitalism: Japan and German Versus the Anglo-Saxon. Oxford University Press, Oxford. 10.1093/acprof: oso/9780199240623.001.0001

Drobetz W., Momtaz P.P. (2019). Corporate Governance in the European M\&A Market. Finance Research Letters, Elsevier. https://www.sciencedirect.com/science/article/abs/pii/S1544612318306421?via\%3Dihu b

Eberhart, R. (2012). Corporate governance systems and firm value: empirical evidence from Japan's natural experiment. Journal of Asia Business Studies, 6, (2), 176-196. https://www.deepdyve.com/lp/emerald-publishing/corporate-governance-systems-andfirm-value-empirical-evidence-from-YUOsGZYoo0

Gilson, R. J., Roe, M. J. (1993). Understanding the Japanese Keiretsu: Overlaps between Corporate Governance and Industrial Organization. Yale Law Journal, 102, (4). Stanford Law and Economics Olin Working Paper; Harvard Public Law Working Paper. SSRN: $\underline{\text { https://ssrn.com/abstract }=2938089}$

Gilson R.J. (2004). Globalizing Corporate Governance: Convergence of Form or Function, in: Convergence and Persistence in Corporate Governance. (eds.) Gordon J. N., Roe M. J., Harvard University, Massachusetts.

Gilson R.J., Milhaupt C.J. (2005). Choice as regulatory reform: the case of Japanese corporate governance. American Journal of Comparative Law, Issue 53, 343-377.

Gordon J.N., Ringe W.G. (2015). The Oxford Handbook of Law and Governance. Oxford University Press, Oxford.

Gordon, J.N., Roe M. (2004). Convergence and persistence in corporate governance. Cambridge University Press. 10.1017/CBO9780511665905. The $\% 20$ Oxford $\% 20$ Handbook\%20of\%20Corporate\%20Law\%20and\%20Governance\% 2 .

Goto, G. (2013). The Outline for the Companies Act Reform in Japan and Its Implications. Journal of Japanese Law, 35, p.p.13-38. file:///D:/Users/wzr/Downloads/22-Artikeltext22-1-10-20141212.pdf.

Hansmann H., Kraakman R. (2000). The End of History for Corporate Law. Harvard Law School John M. Olin Center for Law, Economics and Business Discussion Paper Series. Paper 280, 1-34. http://lsr.nellco.org/harvard_olin/280

Haxhi I., Ees H.V. (2010). Explaining diversity in the worldwide diffusion of codes of good governance. Journal of International Business Studies, 41 (4), 710- 726.

Hattori R., Maeda E. (2000). The Japanese Employment System. Bank of Japan Monthly Bulletin. https://www.boj.or.jp/en/research/brp/ron_2000/data/ron0001a.pdf

Hard decisions. (2018). Special Report Asia faces tough choices in CG reform. Asian Corporate Governance Association and CLSA Limited. file:///D:/Users/wzr/Downloads/CG\%20Watch\%202018\%20(1).pdf.

Hopt Klaus J. (2011). Comparative Corporate Governance: The State of the Art and International Regulation. The American Journal of Comparative Law 2011, 59 (1), 1-73.

Hoshi, T. (1994). The Economic Role of Corporate Grouping and The Main Bank System in: The Japanese Firm: The Sources of Competitive Strength. (eds) Aoki M., Dore R. Oxford: Oxford University Press, 285-309. 
Hoshi T., Kashyap A. (2001). Corporate Financing and Governance in Japan. The MIT Press. Hough J. E., Yakura Ch. (2016). Japan Bar Association Issues New Anticorruption Compliance Guidelines. Morrison \& Foerster LLP | mofo.com.

Inagami T., Whittaker D.H. (2005). The new community firm: Employment, governance, and management reform in Japan. Cambridge University Press, Cambridge. 10.1017/CBO9780511488610.

Itami, H. (2005). Revision of the Commercial Code and Reform of the Japanese Corporate Governance. Japan Labor Review, 2. Tokyo.

Jackson G., Miyajima H. (2007). Introduction: The Diversity and Change of Corporate Governance in Japan. 10.1093/acprof: oso/9780199284511.003.0001.

Jacoby, S. M. (2002). Corporate Governance in Comparative Perspective: Proposals for Convergence. Comparative Labour Law \& Policy Journal, 22.

Japan Corporate Governance. (2020). Corporate Governance Chapters. Nishimura \& Asahi. The Legal 500. https://www.legal500.com/guides/guide/corporate-governance/.

Jeffers, E. (2005). Corporate governance: Toward converging models? Global Finance Journal 2005, 16 (2), 221-232.

Kanda H. (2000). Situations in Japan, Company Law Reform, in: OECD Countries. A Comparative Outlook of Current Trends. Stockholm, Sweden 7-8 December. https://www.oecd.org/daf/ca/corporategovernanceprinciples/1931692.pdf.

Kansaku H., K. Takei K. (2012). Background and Goals New Recommended English translation of "Kansayaku" and" Kansayaku-kai". Japan Audit \& Supervisory Board Members.

Association. http://www.kansa.or.jp/en/New_Recommended_English_translation_of_Kansayaku_an d_Kansayaku-kai.pdf

Karolyi G.A. (2016). The gravity of culture for finance. Journal of Corporate Finance 2016, 41(C), 610-625. www.elsevier.com/ locate/jcorpfin

Kensy, R. (2001). Keiretsu Economy - New Economy? Japan's Multinational Enterprises from a Postmodern Perspective. New York: Palgrave.

Khanna T., Palepu K. (2004). Globalization and Convergence in Corporate Governance: Evidence from Infosys and the Indian software Industry. Journal of International Business Studies, 35, 484-507.

Khanna T., Kogan J., Palepu K. (2006). Globalization and similarities in corporate governance: a cross-country analysis. The Review of Economics and Statistics, 88 (1), 69-90.

Kobayashi A. (2015), Kaisha-ho Nyumon [Introduction to Corporation Law], Tokyo: Daiichi Hohki.

Koyama Y. (1991). Japanese Economy: Another Aspect of Development. The Journal of Economics Niigata University, 51.

Koyama Y. (2003). Bad Loans Problem and Banking System Crisis in Japan. European and Asian Experiences and Public Policy Consideration, University of Greenwich Business School, London, July.

Kwok-bun, Ch., Peverelli P.J. (2010). Cultural Hybridization: A Third Way Between Divergence and Convergence. The Journal of New Paradigm Research .66 (3-4), 219242.

https://www.tandfonline.com/doi/abs/10.1080/02604021003680479?journalCode=gwof $\underline{20}$.

Kuepper J. (2017). Japan's Lost Decade: Brief History and Lessons. International Investing, https://www.thebalance.com/japan-s-lost-decade-brief-history-and-lessons-1979056.

La Porta R., Lopez-De-Silanes F., Shleifer A. (1999). Corporate ownership around the World, Journal of Finance, 54 (2), 471-517 . 
Larcker D., Tayan B. (2011). Corporate Governance Matters. A Closer Look at Organizational Choices and Their Consequences, Pearson Education Inc.

Lee Ch., Allen J. (2013). The Roles and Functions of Kansayaku Boards Compared to Audit Committees. Asian Corporate Governance Association (ACGA) Hong Kong https://www.acga-asia.org/upload/files/advocacy/20170330102329_21.pdf

Lee J. (2014). Hybrid Corporate Governance: The Case of Asia. Review of Contemporary Business Research, 3(3 \& 4), 21-36.

Licht A. (2001). The mother of all path dependencies toward a cross-cultural theory of corporate governance system. Delaware Journal of Corporate Law, 26 (1), 147-205. https://ssrn.com/abstract=266910.

Lovels H. (2016). Japanese Bar Association Publishes New Guidance on Foreign Bribery Prevention, (3.06) https://www.lexology.com/hub/japan.

Masuda E., T. Yoshida T. (2016). New corporate governance structure: Company with audit and supervisory committee. Masuda \& Partners Law Office in Tokyo. https://www.iflr1000.com/NewsAndAnalysis/New-corporate-governance-structureCompany-with-audit-and-supervisory-committee/Index/5997

Mayer C. (1997). Corporate Governance, Competition and Performance. Journal of Law and Society, 24 (1), 152-176.

Milhaupt C., J. (2003). A Lost Decade for Japanese Corporate Governance Reform? What's Changed, What Hasn't, and Why? Columbia Law School, Centre for Law and Economics Working Paper, July, 1-35.

Miyajima H. (2012). Institutional Change and its Economic Consequence in Japan: The bright and dark sides of hybridization. RIETI Discussion Paper Series 12-E-049, 1-43. https://www.rieti.go.jp/jp/publications/dp/12e049.pdf.

Morck R., Nakamura M. (2007). Business Groups and the Big Push: Meiji Japan's Mass privatization and Subsequent Growth. Cambridge University Press, 8 (3), 543-601, September. Available at SSRN: https://ssrn.com/abstract=2269969.

Miyashita, K., Russell, D. W. (1994). Keiretsu: Inside the Hidden Japanese Conglomerates. New York: McGraw-Hill, Inc.

Morikawa, H. (2002). Zaibatsu: The Rise and Fall of Family Enterprises Y Groups in Japan. Tokyo, University of Tokyo Press.

Nakamura, M. (2011). Adoption and Policy implications of Japan's new corporate governance practices after the reform. Asia Pacific Journal of Management, 28, 187-213. https://doi.org/10.1007/s10490-010-9230-8

Nakamura, M. (2016). The Security Market and the Changing Government Role in Japan, Asian. Education and Development Studies, 5 (4), 388-407. https://doi.org/10.1108/AEDS-09-2015-0044.

Nestor S., Thompson J.K. (2000). Corporate Governance Patterns in OECD Economies: Is Convergence Under Way? OECD. http://www.oecd.org/dataoecd/7/10/1931460.pdf

Nottage, L., Wolff, L. T. (2005). Corporate Governance and Law Reform in Japan: From the Lost Decade to the End of History? CLPE Research Paper, 3. Sydney Law School Research Paper No. 06/14, 1(1).

Nottage L., Wolff L., Anderson K. (2009). Corporate Governance in the 21 st Century: Japan's Gradual Transformation. Edward Elgar Publishing.

Nyberg, A., Fulmer, I., Gerhart, B., Carpenter, M. (2010). Agency Theory Revisited: CEO Return and Shareholder Interest Alignment. Academy of Management Journal, 53 (5), 1029-1049.

OECD Corporate Governance Factbook.. (2019). OECD. http://www.oecd.org/daf/ca/Corporate-Governance-Factbook.pdf 
Okabe M. (2009). Corporate Governance in Japan: Evolution, Policy Measures, and Future Issues, in: Codes of Good Governance Around the World. (ed) Felix J., Lopez Iturriaga. Nova Science Publishers, New York.

Okumura H. (1984). Enterprise Groups in Japan. The Journal of Commercial Papers, 147.

Ovsiannikov K. (2017). Corporate Governance Reforms in Japan: Instilling the New Regime. Cogent Business \& Management, 4 (1), 1-16. https://doi.org/10.1080/23311975.2017.1300993

Palkar Ch., Lellapalli R.V. (2015). Divergence or convergence: paradoxes in corporate governance? Corporate Governance, 15(5), 693-705. https://doi.org/10.1108/CG-052015-0066

Patrick H. (2004). Evolving Corporate Governance in Japan. Working Paper No. 220 Working Paper Series Center on Japanese Economy and Business Columbia Business School, 134. https://core.ac.uk/download/pdf/161436199.pdf

Pieterse, J. N. (1994). Globalization as hybridization. International Sociology No 9, . 161-184.

Raupach-Sumiya J. (2000). Reforming Japan's Corporate Governance System: Will the Markets gain Control?, Working Paper 00/2 Erscheinungsort: Tokyo 2000, Deutsches Institut für Japanstudien https://www.dijtokyo.org/publications/WP_00-2.pdf .

Sakamoto M., Harima Y. (2014). Companies Act Reform 2014: Can the new New Topics amendment to the Companies Act of Japan strengthen the corporate governance systems of Japanese listed companies? http://www.cityyuwa.com/english/publication/shared/PDF/JLG201415_cy_56-59.pdf.

Siems M.M. (2010). Convergence in corporate governance: a leximetric approach. The Journal of Corporate Law, 35 (4), 729-756.

Shishido Z. (2001). Reform in Japanese Corporate Law and Corporate Governance: Current Changes in Historical Perspective. The American Journal of Comparative Law, 49 (1), 653-678.

http://scholarship.law.berkeley.edu/cgi/viewcontent.cgi?article=2081\&context=facpubs.

Shishido, Z. (2007). The Turnaround of 1997: Changes in Japanese Corporate Law and Governance. In: Corporate Governance in Japan. (eds.) M. Aoki, G. Jackson, H. Miyajima, Oxford University Press.

Takahashi, E. Madoka S. (2005). The Future of Japanese Corporate Governance: The 2005 Reform. The Journal of Japanese Law, 19(35), 1-35. file:///D:/Users/wzr/Downloads/294-Artikeltext-534-1-10-20150210.pdf

Teranishi J. (2005). Evolution of the Economic System in Japan. Edward Elgar.

The End of Diversity? Prospects for German and Japanese Capitalism. (2003). (eds) Yamamura, K., Streeck, W. ITHACA LONDON, Cornell University Press. Retrieved February 24, 2020, from www.jstor.org/stable/10.7591/j.ctv1nhqd6

The Corporate Auditor System in Japan. (2007). Japan Audit and Supervisory Board Members Association. http://www.kansa.or.jp/en/whats-new/the-corporate-auditor-system-injapan.html

The Oxford Handbook of Law and Governance. (2015). (eds) Gordon J.N., Ringe W.G. Oxford University

Press,

Oxford. The $\% 20$ Oxford $\% 20$ Handbook $\% 20$ of $\% 20$ Corporate $\% 20$ Law $\% 20$ and $\% 20$ Governance $\%$ 2

TSE-Listed Companies White Paper on Corporate Governance. (2019). Tokyo Stock Exchange. https://www.jpx.co.jp/english/news/1020/b5b4pj000002xydaatt/b5b4pj000002xyfw.pdf

Tricker B. (2015). Corporate Governance. Principles, Policies, and Practices, Oxford University Press. Oxford. 
Tsuboi H. (2014). The Role of Outside Directors in Improving Japanese Corporate Governance. Hitotsubashi University Graduate School of International Corporate Strategy, https://hermes-ir.lib.hit-u.ac.jp/rs/bitstream/10086/26836/1/ics020201400103.pdf.

Ueda R. (2015). How is corporate governance in Japan changing? Developments in listed companies and roles of institutional investors, OECD Corporate Governance Working Papers,17. OECD. file:///G:/Gla-Jap.20/5jrw7j3s37hh-en.pdf

West, M. (2001). The Puzzling Divergence of Corporate Law: Evidence and Explanations from Japan and the United States. University of Pennsylvania Law Review, 150 (2), 527-601. doi: $10.2307 / 3312972$

West J. (2019). Better Corporate Governance Is Critical for Japan's Future Prosperity. The Asian Century Institute, September. https://www.brinknews.com/better-corporategovernance-is-critical-for-japans-future-prosperity/

What are the major characteristics and functions of the Japanese keiretsu? http://www.polskaazja.pl/what-are-the-major-characteristics-and-functions-of-the-japanese-keiretsu$\% \mathrm{E} 7 \% \mathrm{~B} 3 \% \mathrm{BB} \% \mathrm{E} 5 \% 88 \% 97$-how-and-why-are-these-changing-today!

Wright D. M., Siegel D.S., Keasy K., Filatotchev I. (2013). The Oxford Handbook of Corporate Governance. Oxford University Press, Oxford.

Yamaguchi, S. (1950). The Banking System in Japan and its Problems. The Annals of the Hitotsubashi Academ, 1(1), 80-90. Retrieved February 6, 2020, from www.jstor.org/stable/43751239

Yao Y. (2009). Historical Dynamics of the Development of the Corporate Governance in Japan. Journal of Politics and Law, 2 (4), 167-174.

Yoshikawa T., Rasheed A.A. (2009). Convergence of corporate governance: critical review and future directions. Corporate Governance: An International Review, 17 (3), 388-404. https://www.academia.edu/14684293/Convergence_of_Corporate_Governance_Critical _Review_and_Future_Directions 